\title{
How, Why and with Whom Do Local Politicians Engage on Facebook?
}

\author{
Eirik Rustad and Øystein Sæbø \\ Center for eGovernment, Department of Information Systems University of Agder, \\ 4604 Kristiansand, Norway \\ \{eirik.rustad, oystein.sabo\}@uia.no
}

\begin{abstract}
This article focuses on how, why and with whom local politicians engage on Facebook. Based on a literature review of the public sphere, eParticipation and research related to social media, we propose a theoretical framework that identifies thematic areas integral to understanding the nature of political participation. The explanatory potential of our 'ENGAGE' model (Exchange, Narcissist, Gather, Accented, General and Expense) is exemplified by conducting a qualitative case study focusing on politicians in a local municipality in southern Norway. The findings indicate various uses of Facebook among the respondents, and a dissonance between what the politicians state as being important (engaging in dialogue with citizens) and what they really do (posting statements). We conclude our paper by discussing the use and usefulness of our proposed model, and by summarising how, why and with whom local politicians use social media.
\end{abstract}

Keywords: eParticipation, political engagement, social media, Facebook, case study.

\section{Introduction}

Despite a growing research interest in the use of social media in the area of eParticipation [1, 2], more work is needed to understand the role of politicians in this capacity. Most studies within the field of eParticipation focus on citizens' roles, whereas the role of politicians is emphasised to lesser degree [3]. This paper focuses on the politicians, by exploring how, why and with whom local politicians engage on Facebook. Based on current literature and empirical findings from an exploratory case study, we introduce an explanatory framework entitled "ENGAGE". Understanding politicians' use of social media is essential to understanding how political discourse among citizens, politicians and other external stakeholders may influence and impact decision-making processes. Facebook is currently the most common social media platform, with most age groups now well represented and with more than one billion members globally. Thus, we choose to focus on politicians' use of Facebook for our research purpose. By doing so, we attempt to understand how and why politicians and citizens alike engage on a technical platform that upholds many of the characteristics normally associated with formal eParticipation efforts. 
Habermas' ideas represent our point of departure to understand how communication between politicians and citizens enhances democracy. Although Habermas has been criticised for leaving organisations and politicians out of the mix [4], many recent eParticipation efforts are based on norms and theoretical backdrop strongly influenced by Habermasian ideas. We argue that the theory of 'the public sphere' [5] is a valuable point of departure to understand eParticipation initiatives. The public sphere is a separate common ground where ordinary citizens can enlighten each other through discussions and find common causes that transform into real politics through the intervention of traditional media, which set the agenda to which politicians must adhere and respond. Our framework aims to apply Habermas' normative concept to a modern-day view of society, where social media plays a major role. Social media provide users the ability to interact, collaborate, contribute and share online contents [6], and to communicate and maintain their networks [7]; the rapid growth in use and number of members increases the importance of understanding its effects on society and people.

We propose a theoretical framework that identifies thematic areas integral to understanding the nature of political participation. By doing so, we aim to identify different attitudes and motivations which are important to understanding various forms of engagement. We illustrate the explanatory potential of the framework by conducting a qualitative case study analysing local politicians' use of Facebook in a Norwegian municipality.

\section{Theoretical Approaches}

Our 'ENGAGE' framework, introduced below, is mainly based upon Habermas' theory of 'the public sphere' [5], the discourse on how technology influences democracy (see ([8]) for a more detailed discussion), and research focusing on the use of social media in the eParticipation area $[1,2,6]$. ENGAGE is an acronym that helps identifying important thematic characteristics in order to gain knowledge of politicians' motivations for using social media. The framework focuses on thematic areas that are related to the theory of the public sphere and eParticipation by finding answers to certain key questions: Who is engaging with each other? What are the outcomes for citizen input? Why is the politician participating?

ENGAGE borrows its structure from 'SLATES' (Search, Links. Authoring, Tags, Extensions and Signals) [9]. McAfee (2006) calls attention to components that should be included in an understanding of 'Enterprise 2.0'. By emphasising which new technologies could enhance effective knowledge sharing within enterprises, this framework helps simplify the thematic areas that are critical to successful operation in a new world. Hence, even though the two schemes do not share a focus on the use of social media in the eParticipation area, the structure of McAfee's (2006) work nevertheless proved important for our purpose.

The framework for our study is presented below, followed by a summary model demonstrating connections between the framework and current streams of research. The individual categories of the ENGAGE model were devised by reviewing 
literature discussing dimensions of the public sphere theory and literature discussing eParticipation, and introduce a conceptual representation of important aspects related to «Web 2.0» technologies, eParticipation and public sphere The scope and length of this paper limits the possibility to discuss in detail the theories upon which the framework is based.

\subsection{ENGAGE}

The framework focuses on thematic areas necessary to understand politicians' behaviour on social media. Building on major themes of the public sphere within an eParticipation context, 'ENGAGE' aims to improve our understanding of the nature of politicians' participation.

E - Exchange. Communication is the core of a thriving democracy [5]. Whether the politician wears his or her private 'hat' or engages in political activity is essential to understanding his or her activity online. In this regard, we do not value exchanges of, for example, cake recipes as equal to an exchange of opinions in a political debate. Thus, centring on exchange involves focusing on the content and context of the online communication exchange.

N - Narcissist. Politicians may or may not consider Facebook to be an isolated arena where 'what happens on Facebook stays on Facebook'. It is important to consider the extent to which politicians change their own opinion, or bring forward prevalent views, into formal political decision-making processes [4]. Politicians may very well be on Facebook solely for the exposure and visibility that it can provide.

G - Gather. Politicians may use social media to engage with citizens either by broadcasting political victories, or by asking for their input on topical issues; both strategies represent important aspects of politics. By preferring the broadcasting strategy with limited gathering of input from other stakeholders, their use of social media becomes more of a one-way dialogue than a deliberative discourse. The distribution of questions asked or statements posed may indicate the type of participation that the politician prefers.

A - Accented. Language is a form of capital that can translate to power, but is also a differentiating factor that can either create distance or 'close the gap' between a political power elite and public participants [5]. An indicator for exclusion or inclusion is the extent to which politicians post detailed or general questions or statements, and how they inform the public and discuss the political process.

G - General. Many groups are marginalised and underrepresented, and eParticipation studies have long warned about the digital divide [3]. Thus, an important area of interest is who the politician receives 'friend requests' from, and who they befriend. Journalists, old classmates, friends, family and other acquaintances are part of politician's networks. It is of common interest to investigate the potential predominance of particular groups in their network, and the potential targeting of specific groups in explaining politicians' participation. 
E - Expense. Available resources limit politicians' engagement on social media. Time, competence and perceived gains are all important factors to consider when we look at the quality of engagement. If a politician does not answer enquiries, or does not actively follow up on discussions and comments, this may diminish citizens' willingness to engage with the politician in question. Expense can therefore be used as a tool to determine whether the participation is meaningful in a comprehensive way, or if it merely resembles a casual pastime without direction.

\subsection{Relationship between 'ENGAGE' and Current Research}

Figure 1 illustrates the relationship between the theoretical backdrop of the public sphere, eParticipation literature and the proposed ENGAGE framework.

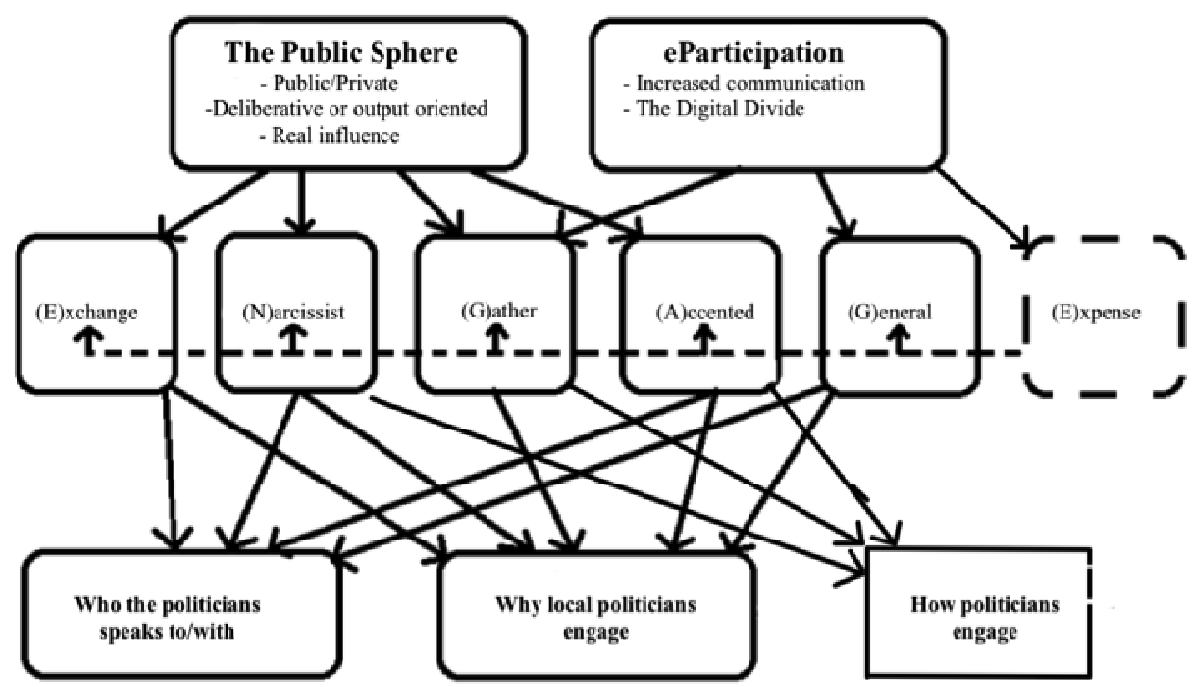

Fig. 1. Relational model for 'ENGAGE'

The theory of public sphere relates to:

- (E)xchange by focusing on engagement of a public or private nature, and prevelant two-way communication. This is a fundamental principle at the core of deliberation in a public sphere.

- (N)arcissist by discussing whether communication has practical implications on policy or political process, or if politicians' communication on social media is isolated from decision-making processes.

- (G)ather by exploring potential prioritising from politicians concerning input and output.

- (A)ccented by discussing how engangement might be influenced by specific goals, and identifying potential target groups. 
eParticipation theory relates to:

- (G)ather by exploring the socio-technical characteristics of social media, and how such systems influence the amount of discourse with external stakeholders.

- (G)eneral by discussing the digital divide by asking who is left out and who is included.

- (E)xpense by discussing resources needed in relation to time spent utilising social media, in comparison to competing communication platforms.

\section{Introducing the Case, Data Collection and Analysis Strategy}

To illustrate the explanatory potential of ENGAGE, we designed a qualitative study to explore politicians' use of Facebook in the Norwegian city of Kristiansand (approximately 75,000 inhabitants). The politicians were selected using a snowball method [10] among city council members with a Facebook account. The politicians were contacted on Facebook and everyone asked agreed to participate. Ages ranged from 20 to 41 years with four female politicians and one male politician interviewed.

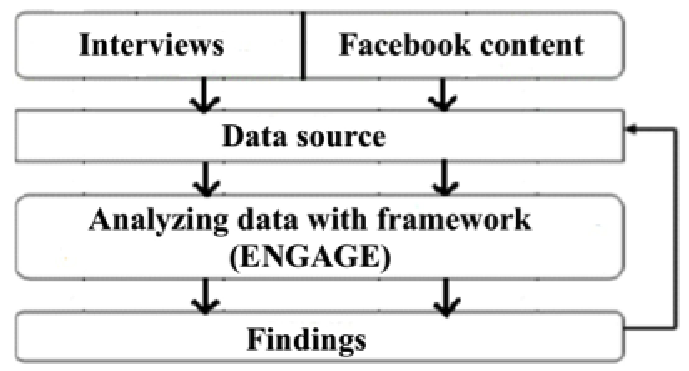

Fig. 2. Data analysis strategy

Given the emphasis on understanding phenomena within their real-life context through a rich description of particular instances [10], it is appropriate to adopt a case study approach [11]. The study is exploratory by nature, aiming to define questions, proposing new constructs and eventually identifying new theoretical propositions, additional constructs and the relationships between constructs [12] that may complement the original framework.

Data came from two sources. The primary source of data was semi-structured interviews covering the thematic areas introduced above (the ARENA framework). Since we limited our case study to interviews with five politicians, we also had a secondary data source, which consisted of a content analysis [13] of data from the five politicians' Facebook pages. Interviews were transcribed and analysed based on a pattern-matching logic, in which themes were identified and put in context within the framework presented. The data from the politicians' Facebook pages were analysed by placing 20 status updates from each politician in a spreadsheet. The spreadsheet categorised the status updates according to their different thematic areas of focus. 


\section{$4 \quad$ Findings}

Below we introduce our findings related to the ENGAGE framework, illustrated by quotations from interviews.

\section{E - Exchange}

'I'm very concious about what I post because I know that my profile is in fact public.' (Respondent \#4).

The politicians are very much aware that what they post on Facebook can turn into news stories. However, they have several concerns on the use of Facebook as a public arena, including a lack of confidence with the technical use of Facebook, as well as how to use the systems in place to develop and maintain their networks. The politicians have limited resources available to really exploit the potential uses of Facebook and social media. Politicians may be wary of becoming tiresome, boring their audience with political discourses that do not necessarily interest everyone.

During the interviews, most politicians expressed believe in using Facebook for two-way dialogue, but the content analyses of their Facebook accounts provided contradictory indicators. The limited number of questions asked to their followers and the number of times the original poster responded to subsequent comments do not uniformly support the claims that politicians engage in two-way dialogues on Facebook. Further questioning as to what constitutes 'two-way dialogue' could have clarified what each individual politician meant by the term. Is 'liking' a statement tantamount to commenting in the eyes of the politician?

\section{N - Narcissist}

'I may have strenghtened my belief in an opinion or had second thoughts because of input or the like. But I have not changed my opininon'.(Respondent 5)

The politicians do not alter their opinions based on inputs and dialogue on social media, but might be open to minor adjustments. This might relate to the fact that politicians post 'status updates' with opinions expressing their strong beliefs, rather than in the form of open questions welcoming inputs to the decision-making processes. Two of the interviewees argued that by mediating wishes expressed by citizens, Facebook might actually influence the political process.

'I have absolutely done that (changed opinions based on inputs on Facebook). Both in political meetings as well in letters or op-eds in the newspaper.' (Respondent 3).

The above statement is an example from one politician stating that she uses Facebook actively as a tool for gathering citizens' opinions on political issues.

'In theory it (Facebook) must be a good arena for discussion, especially for youth, since we are always online and the smartphone is always on the table with Facebook present. Me, I don't discuss much on Facebook because it is 
tiring. The discussion quickly gets out of hand and I have a perception that people discuss just for discussion's sake on Facebook. I discuss so much every day that I can't manage. But in theory it is a good arena.' (Respondent 2).

The statement above echoes other politicians' points of view, while another politician argues that Facebook is a good arena for deliberation because the quality of argumentation is preferable to alternative sources, such as the comment section below online newspaper articles, and since 'everyone' is using Facebook.

\section{G - Gather}

'It is probably input because I scroll and browse more on Facebook than I write myself.'

Most of the 'status updates' analysed in the content analysis are not questions, but opinions or links to online content. Among the five politicians included in our study and out of twenty 'status updates', the highest number of questions was three. Politicians, whenever interviewed, stated that they gather information by browsing Facebook, which takes up a lot of the time that they are 'on' Facebook. Politicians are aware of journalists seizing material posted on their Facebook pages, potentially presenting part of the communication outside its natural context. One politician reported fearing 'flame wars' when posting political 'status updates', thus reducing their willingness to participate in the online discussions, and limiting the potential for improved political deliberation. The content analysis revealed mixed results on how commenting and 'liking' posts related to their own 'status updates' proliferate. The most active politician commented on 13 out of 16 possible 'status updates' that generated comments by external stakeholders, down to a low of three status updates commented out of 15 by the least active politician.

\section{A - Accented}

'[...] if there is something I want to put out there, a purpose may be that one of the journalists I have on Facebook will pick up the story. But that is also why I need to be sure that I want to post it, because then I know it is something I can defend, something that may be printed.' (Respondent 1)

The politicians consider themselves to be very conscious of what they are posting. They know that journalists are watching and, as one politician commented, this represents a double-edged situation in which politicians strive for exposure in traditional media, but at the same time are reluctant to make certain comments or statements out of fear of negative exposure in the same media channels. Most of the 'status updates' indicate that the more general statements dominate. Few of the 'status updates' seem to have specific target groups in mind.

\section{G - General}

'I have made a choice that Facebook is a public arena for me, a politician's arena, not my personal playground.' (Respondent 3)

Some of the politicians view Facebook as a private arena where they do not accept 'friend requests' from unknown individuals, unlike the view expressed by the quotation above. One respondent commented on who the 'friends' are: 
'There are probably many, except those that are my friends and people I know personally, involved in societal matters of some sort. I think that if you took a few hundred people in there that I don't know, but are from Kristiansand, or the southern part of Norway... I would think almost everyone is either politicians, youth politicians, media people, business people or people from the arts. There are probably some people I don't know that "add me” because they are involved in societal matters of some sort.' (Respondent 3).

The politicians' networks of 'friends' do not really indicate any expansion of the public sphere. Their networks are mainly made up of family, friends, colleagues, other politicians and journalists. People in the network that the politicians do not personally know consist mainly of people being active (and visible) in their local society by belonging to elite groups. However, there is a shortcoming in our research approach concerning the network effects. If a 'friend' of the politician comments on something, this might be visible to friends of the friend, depending on the personal settings chosen by the politicians. Hence, a broader audience may possibly be informed by politicians' online activities, compared to those actually able to participate in the discussions.

\section{E - Expense}

'Many will say too much time (is spent on Facebook)! And that is probably true as well. I can say this: generally, independently of if I'm in front of the computer or cell phone, Facebook is always on in the background. As TV is always on in the background for some, Facebook is always on for me.'

(Respondent 3).

All the politicians use Facebook on a daily basis, some for several hours a day. Time spent on Facebook does not easily translate to an activity identified within the framework of this case study, since politicians most probably read more than they write. Moreover, one of our interviewees explained that personal messages are often used to answer comments on the politicians' wall, which are not publicly visible. One politician argues that to successfully use Facebook as a political tool, you need to invest time and presence when engaging your audience; if you don't follow up your initial statement when comments are made, you may lose out on what could have been an interesting discussion.

\section{$5 \quad$ Discussion and Conclusion}

The findings from our case study concerning the thematic areas identified in the current literature are summarised in Table 1. 
Table 1. Case findings summarised

\begin{tabular}{|c|c|}
\hline Thematic area & Main findings \\
\hline Exchange & $\begin{array}{l}\text { Politicians differ in their views on what two-way communication is. } \\
\text { Politicians believe they engage in two-way dialogue, while the } \\
\text { secondary data source points to differences in what politicians consider } \\
\text { to be two-way dialogue. }\end{array}$ \\
\hline Narcissist & $\begin{array}{l}\text { The politicians rarely change their minds on political issues. With } \\
\text { one exception they mainly post opinions that they strongly believe in. }\end{array}$ \\
\hline Gather & $\begin{array}{l}\text { Politicians mostly post statements, not questions. Questions } \\
\text { regarding political issues are not prevalent. Politicians engage on } \\
\text { Facebook through activity that is not necessarily easily monitored. } \\
\text { Some use private messages in an extensive way; others centre their } \\
\text { activity on their 'wall'. Much of the time spent on Facebook is not spent } \\
\text { actively posting or commenting, but browsing profiles, an activity that } \\
\text { may influence politicians but is difficult to measure. }\end{array}$ \\
\hline Accented & $\begin{array}{l}\text { The politicians emphasise that they will use different means in } \\
\text { different parts of the political process, but the main finding is that } \\
\text { politicians are more likely to use Facebook to broadcast outputs than to } \\
\text { gather opinion early in the political processes. The politicians vary the } \\
\text { level of detail in their posts. }\end{array}$ \\
\hline General & $\begin{array}{l}\text { Politicians' friends are mostly made up of already engaged citizens } \\
\text { and cultural, political or civic elites. There is no active strategy for } \\
\text { 'adding' ordinary citizens into the mix. This suggests a strengthening of } \\
\text { bonds between established elites, even though the platform has the } \\
\text { potential to provide more democratic influence, as politicians don't } \\
\text { differentiate among authors of opinions. }\end{array}$ \\
\hline Expense & $\begin{array}{l}\text { The politicians allocate a great deal of time to maintaining a presence } \\
\text { on Facebook. The activity that results from this presence is highly } \\
\text { diverse. One of the politicians stated that while she checks Facebook } \\
\text { four to five times a day, she has posted less than } 20 \text { 'status updates' in } \\
\text { over a year. Others are extremely active in posting status updates or } \\
\text { commenting. Facebook represents a channel in addition to present } \\
\text { communication channels. }\end{array}$ \\
\hline
\end{tabular}


How politicians engage on Facebook varies greatly, with different modes of operation. Most politicians in our study believe in the use of Facebook primarily for collecting opinions from citizens and other stakeholders. However, content analysis of the politicians' Facebook accounts suggest otherwise.

Why politicians engage also varies within our sample. Some view Facebook as a personal and private arena where politicians enter only as private persons, while others view Facebook as a tool for gathering relevant information vital to their role as a politician.

With whom the politicians engage is more uniform. Friends, family, colleagues and journalists are well represented in all respondents' Facebook networks. The remaining 'friends' of the politicians consist mostly of already established elites within cultural or political sectors, or civic society in general.

Politicians with an explicit strategy for how to engage citizens through the use of Facebook are more likely than others to make sense of comments, discussions and other forms of feedback in a meaningful way. Even though most of our respondents do not find their online presence and the input they may receive through their use of Facebook to be especially valuable, with the one exception aiming to use her Facebook presence effectively as valuable resource, social media remains a potentially useful tool if used in a systematic manner.

The general characteristics of social media, and particularly that relevant information can be distributed, gathered and discussed within minutes of posting, may potentially represent a shift in how politicians interact. We argue that politicians may benefit from viewing Facebook as a democratic arena by gathering valuable and relevant information that can influence decisions in political processes. However, our empirical results indicate that politicians, in a local Norwegian context, still have some work to do to strategically harness their use, or non-use, of social media in political discourse.

For now, Facebook as an arena for deliberation may not live up to the strict ideals of public sphere theorists. Habermas' critique of internet as an arena for public deliberation is centred on the fear of echo chamber effects, and the fragmentation that leads to many separate public spheres [14]. Habermas still believes traditional news media is key to setting the agenda. A common criticism when applying public sphere theory to social media is the lack of face-to-face interaction that is an essential aspect of how deliberation should ideally entail [15]. Although there is a gap between a faceto-face meeting between peers, and the nature of Facebook as an arena for engagement, we strongly believe that the use of such media it is a step in the right direction concerning public deliberation. As one of the respondents comment, the «friend» relationship on Facebook is likely to increase incentive to engage by removing barriers. Habermas' critique of «new media» is based mainly on webforums and the like [16]. A non-anonymous arena such as Facebook has arguably different qualities and characteristics than face-to-face encounters, but is still relevant to counter some of Habermas' concerns about an online public sphere.

An interesting observation is the role Facebook and other social media can play in the agenda-setting phase of public decision-making. News-stories published in traditional news media often originate from Facebook. Hence, social media is not only a valuable direct source for news, but plays a mayor role in aggregating news stories, where an increasing number of referrals to news stories originate from social media channels. Facebook may influence the transformation of power from news editors towards a more democratic form of involvement by the public themselves. 
The strength of our proposed model is its potential to encompass a range of important dimensions within different fields of study that are needed in order to obtain a more comprehensive understanding of the phenomena of engagement. The ENGAGE model could easily be confirmed and/or elaborated by further research. Further research is also needed to answer questions regarding how the size of the community influences the quality of the participation. Moreover, the role of the technology could be further investigated, to explore whether the difference in participation (e.g. inability to maintain a dialogue) could be caused by specific technicalities (interface) of the Facebook platform itself rather than politicians' competencies or desire to deepen engagement and participation.

\section{References}

1. Hong, S., Nadler, D.: Which candidates do the public discuss online in an election campaign?: The use of social media by 2012 presidential candidates and its impact on candidate salience. Government Information Quarterly (2012)

2. Linders, D.: From e-government to we-government: Defining a typology for citizen coproduction in the age of social media. Government Information Quarterly (2012)

3. Sæbø, Ø., Rose, J., Skiftenes Flak, L.: The shape of eParticipation: Characterizing an emerging research area. Government Information Quarterly 25, 400-428 (2008)

4. Westling, M.: Expanding the public sphere: The impact of Facebook on political communication. The New Vernacular (2007)

5. Habermas, J.: The Structural Transformation of the Public Sphere. MIT press, Cambridge (1991)

6. McGrath, K., Elbanna, A., Hercheui, M., Panagiotopoulos, P., Saad, E.: Exploring the Democratic Potential of Online Social Networking: The Scope and Limitations of EParticipation. Communications of the Association for Information Systems 30, 16 (2012)

7. Medaglia, R., Rose, J., Nyvang, T., Sæbø, Ø.: Characteristics of social networking services (2009)

8. Päivärinta, T., Sæbø, Ø.: Models of e-democracy (2006)

9. McAfee, A.P.: Enterprise 2.0: The dawn of emergent collaboration. Management of Technology and Innovation 47 (2006)

10. Yin, R.K.: Case study research: design and methods, 4th edn. Sage Publications, Newbury Park (2009)

11. Kirsch, L.J., Beath, C.M.: The enactments and consequences of token, shared, and compliant participation in information systems development. Accounting, Management and Information Technologies 6, 221-254 (1996)

12. Cavaye, A.L.M.: Case study research: a multi-faceted research approach for IS. Information Systems Journal 6, 227-242 (1996)

13. Silverman, D.: Interpreting qualitative data. Sage Publications Limited (2011)

14. Gentikow, B.: Habermas, medienes rolle for den offentlige meningsdannelsen, og en fotnote om Internettet i fire versjoner. Norsk Medietidskrift 1, 55-63 (2009)

15. Habermas, J.: Political communication in media society: Does democracy still enjoy an epistemic dimension? the impact of normative theory on empirical research1. Communication Theory 16, 411-426 (2006)

16. Geiger, R.S.: Does Habermas understand the Internet? The algorithmic construction of the blogo/public sphere. Gnovis: A Journal of Communication, Culture, and Technology 1, 1-29 (2009) 